J. Egypt. Soc. Parasitol. (JESP), 46(1), 2016: 1 - 8

\title{
ASSESSMENT OF THREE BLOOD GENOMIC-DNA PREPARATION METHODS FOR MALARIA MOLECULAR DIAGNOSIS
}

\author{
By \\ SAEED A. AL-HARTHI \\ Department of Parasitology, Faculty of Medicine, Umm Al-Qura University, P.O. \\ Box 13955, Makkah, 21955, Saudi Arabia. Makkah, Kingdom of Saudi Arabia \\ (E-mail: sasharthi@uqu.edu.sa.)
}

\begin{abstract}
Species-specific PCR techniques are highly sensitive and reliable alternatives to classical methods for malaria diagnosis and speciation, especially in endemic regions under advanced control or elimination programs where asymptomatic and low-density infections are increasingly reported. Nevertheless, the performance of these techniques is directly affected by the quality of isolated DNA templates. A Plasmodium falciparum/vivax-specific diagnostic Nested-PCR ( $P f / P v$ N-PCR) was used to assess three DNA preparation methods, Qiagen ${ }^{\circledR}$ MiniChromatographic kit (QIAmp $\left.{ }^{\circledR}\right)$ and Jena-Biosciences ${ }^{\circledR}$ DNA isolation kit (JB $\left.{ }^{\circledR}\right)$ for genomic DNA extraction from EDTA-preserved whole blood samples, and Whatman-FTA ${ }^{\circledR}$ purification reagent $(F T A \circledR)$ for DNA preparation from dry blood spots (DBS) collected onto FTA®cards.

A total of 84 out of 137 blood specimens collected from malaria suspicious febrile patients who visited five health care centres in south-western endemic localities of Saudi Arabia were found $P$. falciparum positive by at least one method. Among these, only $76(90 \%)$ were reported $P$. falciparum malaria positive by two expert microscopists. No other species of Plasmodium were detected. Pf/Pv N-PCR revealed 84/84 (100\%), 75/84 (89\%), and 81 (96\%) $P$. falciparum positive samples using DNA templates prepared by QIAmp ${ }^{\circledR}, J B \circledR$, and FTA® purification methods, respectively. Therefore, $P f / P v$ N-PCR, when applied to QIAmp ${ }^{\circledR}$ DNA templates showed to be a highly sensitive diagnostic method, particularly useful for submicroscopic specimens from clinically malaria suspicious patients in endemic areas. On the other hand, $P f / P v$ N-PCR of FTA ${ }^{\circledR}$-DBS DNA templates revealed 5 positive cases missed by microscopy, encouraging its use as an affordable field semi-adapted protocol for malaria active screening, especially in remote rural regions with limited laboratory infrastructure.

Key words: Malaria diagnosis, Nested-PCR, DNA Extraction, EDTA-Blood, FTA ${ }^{\circledR}$-Blood Spots.
\end{abstract}

\section{Introduction}

Malaria continues as the most important vector-transmitted infection in the world, particularly present in the tropics and subtropics. Five species of protozoan parasites belonging to the genus of Plasmodium are known to cause human malaria; $P$. falciparum, $P$. vivax, $P$. malariae, $P$. ovale, and $P$. knowlesi, the only zoonotic form (WHO, 2014; Wesolowski et al, 2015). Plasmodium parasites are transmitted to humans by about 70 species of blood-feeding Anopheles female mosquitoes (Sinka et al, 2012). In 2013, according to estimates of the World Health Organization, over 3 billion people were considered at risk of acquiring the infection, 198 million cases of malaria occurred and 584000 died from the disease worldwide, particularly from $P$. falciparum malaria, the malignant form (WHO, 2014). In Saudi Arabia, autochthonous malaria cases are mostly registered in the southwestern region, where $P$. falciparum accounts for about $90 \%$ of reported cases, and where the disease existence is perpetuated by continuous importation from neighbouring Yemen (Alkhalife, 2003; MOH, 2005). Although significant decrease of locally transmitted malaria was achieved during the last decades after remarkable malaria control efforts (WHO, 2005), there is always a major risk for re-introduction of the 
disease by millions of visitors coming for work or Ummrah and Hajj, in particular from the endemic areas (Alkhalife, 2003; Al-Tawfiq, 2006; Al-Harthi, 2015). It has already been reported that a considerable number of pilgrims carrying malaria parasites visits annually the country (Khan et $a l, 2002)$.

In many endemic regions worldwide, it is still a common practice to rely on clinical signs solely for malaria diagnosis and consequent treatment, especially during the transmission pick seasons (White, 2004). El-Bahnasawy et al. (2013) stated that in spite of the great technological progress achieved worldwide, still arthropod borne infectious diseases is a puzzle disturbing the health authorities and that malaria tops the prevalent human mosquito-borne diseases. Classically, laboratory confirmation of the clinically suspected malaria cases is done by the microscopic examination of Giemsa-stained thick and thin blood films, but this centennial technique is capable of reliable diagnosis only when performed by skilled microscopists and is limited by the parasitaemia level (Avila and Ferreira, 1996; Cheesbrough, 1998). Different rapid diagnostic tests (RDTs) were also developed for diagnosis of malaria by detection of genus-specific or even species-specific circulating antigens, namely HRP2 and pLDH molecules circulating in blood. But, since their introduction, the RDTs showed very varied grades of specificity and their sensitivity depends on parasitaemia level (Forney et al, 2001; Cheesbrough, 2009; Wongsrichanalai et al, 2007). Then, molecular tools, namely PCR and PCR-modified techniques like Multiplex, Nested, and Real Time-PCR had become the most sensitive alternative to classical diagnostic methods, especially in regions with high incidence of asymptomatic chronic cases (Proux et al, 2011). Several experimental investigations of different molecular tests confirmed their high sensitivity as confirmatory malaria diagnostic techniques for the sub-microscopic cases (Coura et al, 2006; Al-Harthi and Jamjoom, 2008). More progress will be achieved towards the elimination of malaria; more must be the need of highly sensitive diagnostic tools to detect sub-microscopic cases that may sustain transmission (Ouedraogo et al., 2009). A Plasmodium falciparum/vivax species-specific Nested PCR (Pf/Pv NPCR) targeting Plasmodium $18 \mathrm{~S}$ SSU rRNA genes able to detect and differentiate between both species was adapted from Snounou et al. (1993) and Singh et al. (1996) to carry out the present study. $P f / P v$ N-PCR was used to assess three commercial tools for genomic DNA templates preparation from whole blood samples collected from $P$. falciparum/vivax endemic Saudi south-western localities (Al-Harthi, 2015).

\section{Subjects, Material and Methods}

Collection of blood samples: A total of 137 samples were collected from febrile patients complaining of malaria associated symptoms, as considered by physicians on duty in five health care centres of Saudi south-western province of Jazan between 2009 and 2013, after their consent. Specimens were collected and transported in EDTA-treated tubes and onto WhatmanFTA-cards (Whatman, Florham Park, NJ) as dry blood spots (DBS). Two negative whole blood samples from healthy individuals living in non-endemic areas and the $P$. falciparum cultured reference strain 3D7, kindly provided by Liverpool School of Tropical Medicine, were used as negative and positive controls, respectively.

Microscopic examination: For each patient, on arrival, thick and thin blood smears were routinely prepared for malaria diagnosis. Only thin blood films were fixed in methanol and both films were stained using 1\% Giemsa solution. Stained smears were then examined twice by two expert microscopists using $\mathrm{x} 100$ objective. Parasitaemia level was determined on thick smears as $1+$ for $1-10$ parasites per 100 
fields; $2+$ for 11-100 parasites per 100 fields; $3+$ for 1-10 parasites per a single field; and 4+ for more than 10 parasites per single field according to standards of WHO (1991). At least 100 thick film fields were examined by each microscopist before a slide was considered negative. Plasmodium parasites species were determined using thin blood films.

Genomic DNA templates preparation: DNA templates were extracted from the EDTA-preserved whole blood samples using two kits following the manufacturers' protocols, QIAmp $^{\circledR}$ DNA Blood Minicolumns Kit (Qiagen, Hilden, Germany) using $200 \mu \mathrm{l}$ of blood samples, and JenaBiosciences $^{\circledR}$ DNA isolation/precipitation kit (Jena Bioscience GmbH, Germany) using $300 \mu \mathrm{l}$ of blood samples, both through centrifugation method. Extracted DNA samples were adjusted to $200 \mu \mathrm{l}$ for QIAmp ${ }^{\circledR}$ isolates and $300 \mu \mathrm{l}$ for $\mathrm{JB}^{\circledR}$ extracts in recommended elution or dilution buffer. For DNA templates preparation from FTA $^{\circledR}$-cards DBS, a $2.5 \mathrm{~mm}$ diameter piece was cut using a clean punch from each DBS. The snippets were separately treated by Whatman-FTA ${ }^{\circledR}$ commercial reagent (Whatman, Florham Park, NJ) and TE buffer. They were washed three times at room temperature in $0.2 \mathrm{ml}$ PCR tubes using $100 \mu \mathrm{l}$ of $\mathrm{FTA}^{\circledR}$ reagent by moderate manual rocking, for 5 minutes each, and rinsed twice in $200 \mu \mathrm{l}$ of TE buffer for 5 minutes. The snippets were used directly as template in first PCR reactions.

Pf/Pv N-PCR: A diagnostic Nested PCR targeting Plasmodium 18S SSU rRNA genes was adapted from Snounou et al. (1993). The assay consists in a first Plasmodium genus-specific PCR reaction using rPLU6: TTA AAA TTG TTG CAG TTA AAA CG and rPLU5: CCT GTT GTT GCC TTA AAC TT oligonucleotides, followed by a $P$. falciparum and vivax species-specific Multiplex Nested-PCR using PfF: TTA AAC TGG TTT GGG AAA ACC AAA TAT ATT and PfR: ACA CAA
TGA ACT CAA TCA TGA CTA CCC GTC oligonucleotides specific to $P$. falciparum, and $P v F$ : CGC TTC TAG CTT AAT CCA CAT AAC TGA TAC and $P v R$ : ACT TCC AAG CCG AAG CAA AGA AAG TCC TTA specific to $P$. vivax. PCR reactions were carried out in final volumes of $25 \mu \mathrm{l}$ containing $1.5 \mu \mathrm{l}$ template DNA obtained by QIAmp ${ }^{\circledR}$ and JB ${ }^{\circledR}$ kits, and $2.5 \mathrm{~mm}$ diameter FTA $^{\circledR}$-cards treated snippets, $0.2 \mu \mathrm{M}$ of each primer, and $12.5 \mu \mathrm{l}$ of $2 \mathrm{x}$ HotStart $^{\mathbb{B}}$ Taq MasterMix (Qiagen, USA). The following thermo-cycling scheme was used in the first reaction: $95^{\circ} \mathrm{C} / 15 \mathrm{~min}, 40 \times\left(94^{\circ} \mathrm{C} / 30 \mathrm{~s}, 57^{\circ} \mathrm{C}\right.$ $135 \mathrm{~s}, 62^{\circ} \mathrm{C} / 70 \mathrm{~s}$ ) and a final extension step at $65^{\circ} \mathrm{C} / 5 \mathrm{~min}$. Nested reactions were performed using $2 \mu \mathrm{l}$ of $\mathrm{rPLU6} / \mathrm{rPLU}$ 5-PCR products under the following conditions: $95^{\circ} \mathrm{C} / 15 \mathrm{~min}, \quad 40 \mathrm{x}\left(94^{\circ} \mathrm{C} / 30 \mathrm{~s}, \quad 54^{\circ} \mathrm{C} / 30 \mathrm{~s}\right.$, $66^{\circ} \mathrm{C} / 40 \mathrm{~s}$ ) and $66^{\circ} \mathrm{C} / 5 \mathrm{~min}$, producing an amplicon of $205 \mathrm{bp}$ if $P$. falciparum DNA is present and $120 \mathrm{bp}$ if $P$. vivax specific DNA was present. PCR products were separated by electrophoresis onto $1.4 \%$ agarose gels alongside a $100 \mathrm{bp}$ scale DNA ladder and visualized using EtBr staining.

\section{Results}

A total of 76 out of 137 specimens collected from febrile patients in Jazan province during high transmission seasons between 2009 and 2013 were confirmed on site as $P$. falciparum malaria positive by expert microscopists. No other Plasmodium species were detected among all patients. Reported parasitaemia levels were estimated using Giemsa-stained thick blood smears as $1+$ to $4+$ (Tab. 1).

Results of $P f / P v$ N-PCR analysis of the 137 DNA templates prepared separately by QIAmp $^{\circledR}$, JB $\AA$, FTA $^{\circledR}$ are collected relatively to the samples' parasitaemia grades as determined by microscopy (Tab. 2). The first agarose gel of separated $P f / P v$ N-PCR products is presented herein as a model (Fig. 1). No PCR products were obtained with two negative control DNA templates obtained from blood samples of healthy 
individuals living in non-endemic areas and prepared by the three studied methods. 3D7 P. falciparum reference strain DNA samples showed positive results in all runs. 8 samples of malaria clinically suspicious, but negative by microscopy, were found positive by Nested-PCR.

In total, 84/137 included specimens were

Table1: Microscopic examination performed by two expert microscopists.

\begin{tabular}{|l|c|c|c|c|c|c|}
\hline \multirow{2}{*}{ Microscopy } & \multicolumn{5}{|c|}{ Parasitaemia level } & \multirow{2}{*}{ Total samples } \\
\cline { 2 - 7 } & Neg. & $1+$ & $2+$ & $3+$ & $4+$ & \\
\hline Microscopic examination & 61 & 18 & 22 & 29 & 7 & \multirow{2}{*}{737} \\
\hline Total samples & 61 & \multicolumn{6}{|c|}{76} & \\
\hline
\end{tabular}

Table 2: Sensitivity of $P f / P v$ N-PCR using DNA templates prepared by QIAmp ${ }^{\circledR}, \mathrm{JB}^{\circledR}$, and FTA ${ }^{\circledR}$ methods relatively to parasitaemia level.

\begin{tabular}{|c|c|c|c|c|}
\hline \multirow{2}{*}{ Parasitaemia level } & \multirow{2}{*}{ Number of Samples } & \multicolumn{3}{|c|}{+ ve falciparum-specific Nested-PCR } \\
\cline { 3 - 5 } & & QIAmp ${ }^{\circledR}$ & JB ${ }^{\circledR}$ & FTA ${ }^{\circledR}$ \\
\hline -ve & 53 & 0 & 0 & 0 \\
\hline $1+$ & $18+8^{*}$ & $26(100 \%)$ & $19(73 \%)$ & $23(88 \%)$ \\
\hline $2+$ & 22 & $22(100 \%)$ & $21(95 \%)$ & $22(100 \%)$ \\
\hline $3+$ & 29 & $29(100 \%)$ & $28(97 \%)$ & $29(100 \%)$ \\
\hline $4+$ & 7 & $7(100 \%)$ & $7(100 \%)$ & $7(100 \%)$ \\
\hline
\end{tabular}

$8^{*}$ : negative samples by microscopic examination, but malaria positive by at least one molecular technique estimated at minimal parasitaemia level $(1+)$.

Table 3: Relative sensitivity, specificity, positive and negative predictive values of $P f / P v$ N-PCR using DNA templates prepared by QIAmp ${ }^{\circledR}, \mathrm{JB}^{\circledR}$, and FTA ${ }^{\circledR}$ versus microscopic examination.

\begin{tabular}{|c|c|c|c|c|c|}
\hline Technique & Specimens & Sensitivity & Specificity & +ve P.V. & -ve P.V. \\
\hline Microscopy & Thick blood smear & $76 / 84(90 \%)$ & $53 / 53(100 \%)$ & $84 / 84(100 \%)$ & $53 / 61(87 \%)$ \\
\hline \multirow{3}{*}{$P f / P v$ N-PCR } & QIAmp $^{\circledR}$ & $84 / 84(100 \%)$ & $53 / 53(100 \%)$ & $84 / 84(100 \%)$ & $53 / 53(100 \%)$ \\
\cline { 2 - 6 } & $\mathrm{JB}^{\circledR}$ & $75 / 84(89 \%)$ & $53 / 53(100 \%)$ & $84 / 84(100 \%)$ & $53 / 62(85 \%)$ \\
\cline { 2 - 6 } & FTA $^{\circledR}$ & $81 / 84(96 \%)$ & $53 / 53(100 \%)$ & $84 / 84(100 \%)$ & $53 / 56(95 \%)$ \\
\hline
\end{tabular}

Fig. 1: Agarose gel of $P f / P v$ N-PCR products of malaria patients (S1, S2,) blood DNA templates prepared by QIAmp $^{\circledR}$ (lanes Q), JB ${ }^{\circledR}(\mathrm{JB})$, and FTA ${ }^{\circledR}(\mathrm{F})$. A $100 \mathrm{bp}$ molecular weight marker was separated in lane M.

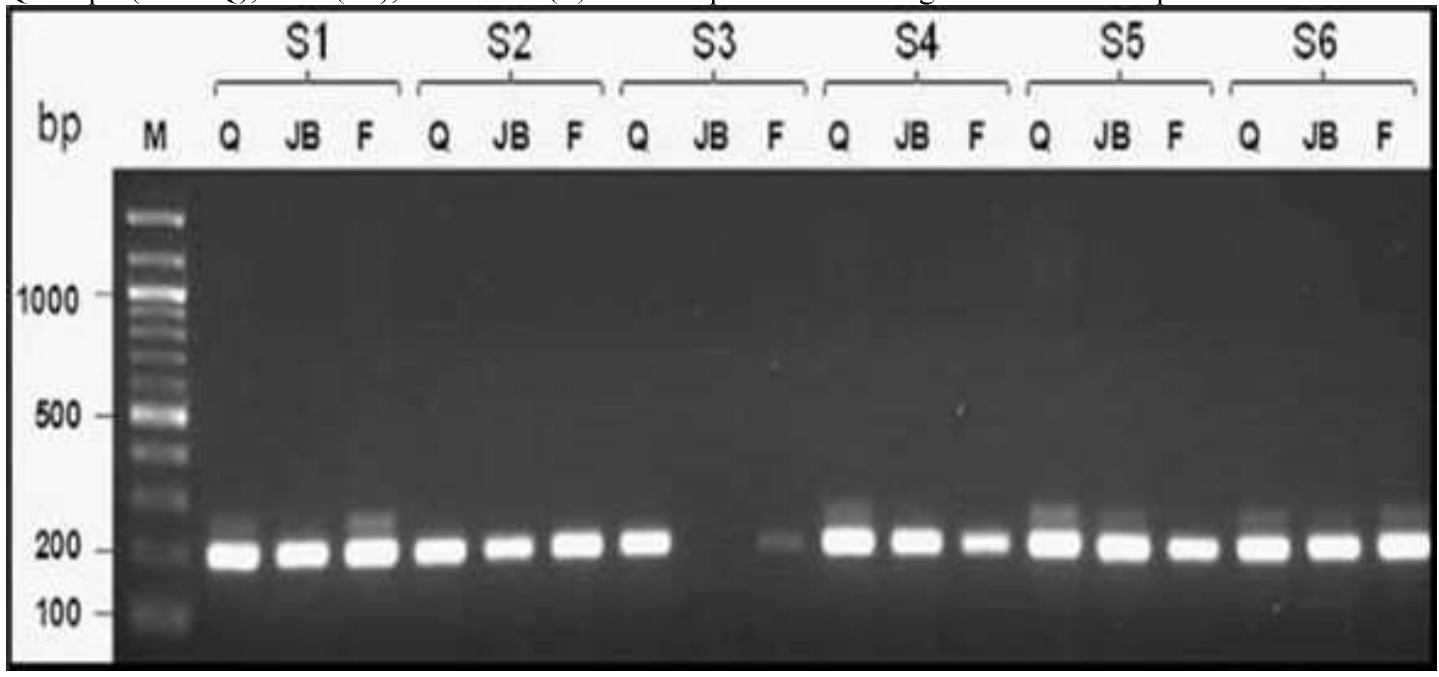




\section{Discussion}

Despite the significant progress achieved by malaria control program in Saudi Arabia, the disease remains a serious health issue, particularly in endemic southwestern regions where $P$. falciparum is the most predominant species accounting for over $90 \%$ of autochthonous cases and $P$. vivax for the remaining ones, and where patients with clinically suspected malaria signs are frequently encountered (Omar et al, 1999; Al-Harthi and Jamjoom, 2008). Furthermore, important numbers of imported malaria cases are being reported annually, particularly from neighbouring endemic bordering areas of Yemen (Alkhalife, 2003; Al-Tawfiq, 2006; Al-Harthi, 2015, Bamaga et al, 2015). Laboratory confirmation of malaria cases rely basically on microscopic examination of Giemsastained thick and thin blood smears, a laborious and highly subjective method showing low sensitivity with chronic and asymptomatic carriers (WHO, 2013). As more progress will be achieved towards the elimination of malaria, more will be the need of highly sensitive diagnostic tools to confirm sub-microscopic clinical cases for a prompt and correct treatment to avoid overtreatment and consequent origination of malaria resistant strains (Schneider et al, 2007; Ouedraogo et al, 2009). Besides, the implementation of more efficient diagnostic tools is vital in active surveys, especially for detection of chronic asymptomatic infections that may sustain transmission hindering any malaria elimination expectations.

Currently, the only diagnostic tools totally adapted to field screenings are the rapid diagnostic tests (RDTs), which extensive evaluations showed discrepant levels of sensitivity and specificity with limitations in detecting parasitaemia levels lower than 200 parasites $/ \mu \mathrm{L}$ in $P$. falciparum infections, and even higher with $P$. vivax (Forney et al, 2001; Branch et al, 2005; Wong- srichanalai et al, 2007; Bharti et al, 2008; Cheesbrough, 2009). This impede the possible use of RDTs as single diagnostic tool for monitoring malaria elimination programs, where probably more than a detection tool will be needed in combination to achieve effective results in health care centers and surveillance activities (McMorrow et al, 2011). PCR and PCR-modified methods had proven highly sensitive for malaria diagnosis and differentiation, and are being considered as the gold standard method in many health and research settings (Rubio et al, 2002; Hanscheid and Grobusch, 2002; Moody, 2002). In this study, we used a SSU rRNA genes based $P f / P v$ N-PCR (Snounou et al., 1993) to assess the suitability of DNA templates prepared from 137 collected samples by QIAmp ${ }^{\circledR}$ and $\mathrm{JB}^{\circledR}$ isolation kits from whole EDTA-preserved blood samples and FTA ${ }^{\mathbb{B}}$ specific reagent for DBS.

A total of 84 samples were found $P$. falciparum positive by at least one method, while only 76 among these were positive by microscopic examination showing different parasitaemia levels escalating from $1+$ to $4+$. The use of SSU rRNA genes as DNA targets in malaria molecular diagnosis, parasites speciation, and mixed infections identification has proven to be highly effective (Singh et al, 1996). The $P f / P v$ NPCR applied to QIAmp ${ }^{\circledR}$-DNA templates has been able to detect $P$. falciparum specific DNA in eight samples misdiagnosed by microscopic examination in hands of two experts. It has been reported in several studies that sub-microscopic cases detectable only by sensitive PCR techniques are much more prevalent in endemic areas than previously estimated (Bottius et al, 1996; Okell et al, 2012). In summary, QIAmp ${ }^{\circledR}$ extraction method provided better DNA templates for amplification by $P f / P v$ N-PCR, achieving $100 \%$ relative sensitivity compared to $96 \%$, and $89 \%$ achieved using DNA templates prepared by FTA $^{\circledR}$ and $\mathrm{JB}^{\circledR}$ methods, respectively. Curiously, 
$\mathrm{JB}^{\circledR}$ isolated DNA templates from two blood samples with relatively significant parasitaemia levels, $2+$ and $3+$, did not yield positive $P f / P v$ N-PCR results in three different trials, this can be explained by the presence of strong PCR inhibitors due to the nature of chemical precipitation process used in this purification kit.

It has been experimentally well established that filter matrices impregnated with chemical stabilizers offer an excellent support for blood samples collection and preservation as a source of DNA material for posterior molecular investigations ( $\mathrm{Li}$ et al, 2004; Ndunguru et al, 2005). In the present study, $P f / P v$ N-PCR amplifications of FTA ${ }^{\circledR}$ stored and prepared DNA templates showed a sensitivity of $96 \%(81 / 84)$ revealing 5 more positive cases missed by microscopy. And, the 3 FTA $^{\circledR}$-false negative samples were all sub-microscopic cases with minimal parasitaemia levels detected only by N-PCR when QIAmp ${ }^{\circledR}$ purified DNAs were used. It has been reported by the manufacturer and other experimental studies that FTA $^{\circledR}$ blood DNA storage and purification system provides good quality DNA templates for PCR runs free of heme, contaminants, and other possible inhibitors, with less risk of loss or degradation (Long et al, 1995; Whatman Ltd, 2002). Although, $P f / P v$ N-PCR using FTA $^{\circledR}$-DNAs showed relatively less sensitive than when using QIAmp ${ }^{\circledR}$-DNAs, the ability of this method to identify a considerable number of sub-microscopic malaria infections together with its advantage of collecting and transporting finger prick DBS encourages its implementation in active epidemiological surveys, especially in remote rural areas lacking adequate facilities for collecting and maintaining intravenous whole blood samples in ideal conditions.

\section{Conclusion}

The highest diagnostic indices were achieved by $P f / P v$ N-PCR when applied to QIAmp ${ }^{\circledR}$ isolated DNA templates, making it a molecular tool very useful for diagnosis of sub-microscopic malaria infections, especially in endemic localities. Yet, the significant performance $(96 \%)$ obtained by $P f / P v$ N-PCR using FTA ${ }^{\circledR}$ treated DBS, encourages its use as a field semi-adapted alternative for malaria active surveys during control and elimination programs in remote rural regions.

\section{Acknowledgements}

This work was financially supported by the Institute of Scientific Research and Revival of Islamic Heritage.

Thanks are due to all the Medical Staff and Technicians in the Health Care Centres who kindly contributed in this study.

\section{References}

Al-Harthi, SA, 2015: Comparison of a genusspecific conventional PCR and a species-specific Nested-PCR for malaria diagnosis using FTA collected samples from Kingdom of Saudi Arabia. J. Egypt. Soc. Parasitol. 45, 3:45766.

Al-Harthi, SA, Jamjoom, MB, 2008: PCR assay in malaria diagnosis using filter paper samples from Jazan region, Saudi Arabia. J. Egypt. Soc. Parasitol. 38, 3:693-706.

Alkhalife, IS, 2003: Imported malaria infections diagnosed at the Malaria Referral Laboratory in Riyadh, Saudi Arabia. Saudi Med. J. 24:1068-72.

Al-Tawfiq, JA, 2006: Epidemiology of travelrelated malaria in a non-malarious area in Saudi Arabia. Saudi Med. J. 27:86-9.

Avila, SL, Ferreira, AW, 1996: Malaria diagnosis: a review. Braz. J. Med. Biol. Res. 29, 4:431-43.

Bamaga, OA, Mahdy, MA, Lim, YA, 2015: Frequencies distribution of dihydrofolate reductase and dihydropteroate synthetase mutant alleles associated with sulfadoxine-pyrimethamine resistance in Plasmodium falciparum population from Hadhramout Governorate, Yemen. Malar. J. 14, 1:516-20

Bharti, PK, Silawat, N, Singh, PP, Singh, MP, Shukla, M, et al, 2008: The usefulness of a new rapid diagnostic test, the first response malaria Combo (pLDH/HRP2) card test, for malaria diagnosis in the forested belt of central India. Malar J. 11, 7:126. 
Bottius, E, Guanzirolli, A, Trape, JF, Rogier, C, Konate, L, Druilhe, P, 1996: Malaria: even more chronic in nature than previously thought; evidence for subpatent parasitaemia detectable by the polymerase chain reaction. Trans. R. Soc. Trop. Med. Hyg. 90:15-9.

Branch, O, Casapia, WM, Gamboa, DV, Hernandez, JN, Alava, FF, et al, 2005: Clustered local transmission and asymptomatic Plasmodium falciparum and Plasmodium vivax malaria infections in a recently emerged, hypoendemic Peruvian Amazon community. Malar. J. 23, 4:27-32.

Cheesbrough, M, 1998: Importance of laboratory practice in district health care services. In: District Laboratory Practice in Tropical Countries, Part 1- Tropical Health Technology. Cambridge.

Cheesbrough, M, 2009: Importance of laboratory practice in district health care services. In: District Laboratory Practice in Tropical Countries, $\left(2^{\text {nd }}\right.$ ed.) Update. Tropical Health Technology, Cambridge.

Coura, JR, Suárez-Mutis, M, Ladeia-And rade, S, 2006: A new challenge for malaria control in Brazil: asymptomatic Plasmodium infection. Mem. Inst. Oswaldo Cruz 101, 3: 229-37.

El-Bahnasawy, MM, Fadil, EE, Morsy, TA, 2013: Mosquito vectors of infectious diseases: are they neglected health disaster in Egypt? J.

Egypt. Soc. Parasitol. 43, 2:373-86.

Forney, JR, Magill, AJ, Wongsrichanalai, C, Sirichaisinthop, J, Bautista, CT, et al, 2001: Malaria rapid diagnostic devices: performance characteristics of the ParaSight $\mathrm{F}$ device determined in a multisite field study. J. Clin. Microbiol. 39, 8:2884-90.

Hanscheid, T, Grobusch, MP, 2002: How useful is PCR in the diagnosis of malaria? Trends Parasitol. 18:395-8.

Khan, AS, Qureshi, F, Shah, AH, Malik, S A, 2002: Spectrum of malaria in Hajj pilgrims in the year 2000. J. Ayub. Med. Coll. Abbottabad. 14, 4:19-21.

Li, CC, Beck, IA, Seidel, KD, Frenkel, LM, 2004: Persistence of human immunodeficiency virus type 1 subtype B DNA in dried-blood samples on FTA filter paper. J. Clin. Microbiol. 42, 8:3847-9.

Long, GW, Fries, L, Watt, GH, Hoffman, SL, 1995: Polymerase chain reaction amplifi- cation from Plasmodium falciparum on dried blood spots. Am. J. Trop. Med. Hyg. 52:344-6. McMorrow, ML, Aidoo, M, Kachur, SP, 2011: Malaria rapid diagnostic tests in elimination settings, can they find the last parasite? Clin. Microbiol. Infect. 17, 11:1624-31.

MOH, 2005: Health Statistic Book, Ministry of Health (http://www.moh.gov.sa /statistics/ 1425/Annual_Report.htm).

Moody, A, 2002: Rapid diagnostic tests for malaria parasites. Clin. Microbiol. Rev. 15, 1: 66-78.

Ndunguru, J, Taylor, NJ, Yadav, J, Aly, H, Legg, JP, et al, 2005: Application of FTA technology for sampling, recovery and molecular characterization of viral pathogens and virus-derived transgenes from plant tissues. Virol. J. 18, 2:45.

Okell, LC, Bousema, T, Griffin, JT, Ouedraogo, AL, Ghani, AC, et al, 2012: Factors determining the occurrence of submicroscopic malaria infections and their relevance for control. Nat. Commun. 3:1237-42.

Omar, MS, Malik, GM, Al-Amari, OM, Abdalla, SE, Moosa, RA, 1999: The rapid manual ParaSight-F test for diagnosing Plasmodium falciparum malaria in Saudi Arabia. Ann. Saudi Med. 19, 2:159-62.

Ouedraogo, AL, Bousema, T, Schneider, P, de Vlas, SJ, Ilboudo-Sanogo, E, et al, 2009: Substantial contribution of submicroscopical Plasmodium falciparum gametocyte carriage to the infectious reservoir in an area of seasonal transmission. PLoS One. 22;4(12):e8410.

Proux, S, Suwanarusk, R, Barends, M, Zwang, J, Price, RN, et al, 2011: Considerations on the use of nucleic acid-based amplification for malaria parasite detection. Malar. J. 28, 10: 323-6.

Rubio, JM, Post, RJ, van Leeuwen, WM, Henry, MC, Lindergard, G, et al, 2002: Alternative polymerase chain reaction method to identify Plasmodium species in human blood samples: the semi-nested multiplex malaria PCR (SnM-PCR). Trans. R. Soc. Trop. Med. Hyg. 96:S199-204.

Schneider, P, Bousema, JT, Gouagna, LC, Otieno, S, van de Vegte-Bolmer, $M$, et al, 2007: Submicroscopic Plasmodium falciparum gametocyte densities frequently result in mosquito infection. Am. J. Trop. Med. Hyg. 76. 3: 470-4. 
Singh, B, Cox-Singh, J, Miller, AO, Abdullah, MS, Snounou, G, et al, 1996: Detection of malaria in Malaysia by nested polymerase chain reaction amplification of dried blood spots on filter papers. Trans. R. Soc. Trop. Med. Hyg. 90:519-21.

Sinka, ME, Bangs, MJ, Manguin, S, RubioPalis, Y, Chareonviriyaphap, T, et al, 2012: A global map of dominant malaria vectors. Parasit. Vectors 4, 5:69-72.

Snounou, G, Viriyakosol, S, Jarra, W, Thaithong, S, Brown, KN, 1993: Identification of the four human malaria parasite species in field samples by the polymerase chain reaction and detection of a high prevalence of mixed infections. Mol. Biochem. Parasitol. 58:283-92.

Wesolowski, R, Wozniak, A, Mila-Kierzen kowska, C, Szewczyk-Golec, K, 2015: Plasmodium knowlesi as a threat to global public health. Korean J. Parasitol. 53, 5:575-81.
Whatman, Ltd. 2002: FTA ${ }^{\circledR}$ Protocols: Collect, Transport, Archive And Access Nucleic Acids: All at Room Temperature. (http://www. carl-roth.de/website/ de-de/pdf/FTA).

White, NJ, 2004: Antimalarial drug resistance. J. Clin. Invest. 113:1084-92.

WHO, 1991: Basic Malaria Microscopy. Geneva, Switzerland.

WHO, 2005: Overview of malaria control activities and programme progress. (http://rbm. who. int/wmr2005/profiles/saudiarabia.pdf).

WHO, 2013: World Malaria Report 2013. Geneva: WHO Press.

WHO, 2014: World malaria report 2014. Geneva: WHO Press.

Wongsrichanalai, C, Barcus, MJ, Muth, S, Sutamihardja, A, Wernsdorfer, WH, 2007: A review of malaria diagnostic tools: microscopy and rapid diagnostic test (RDT). Am. J. Trop. Med. Hyg. 77:119-27. 